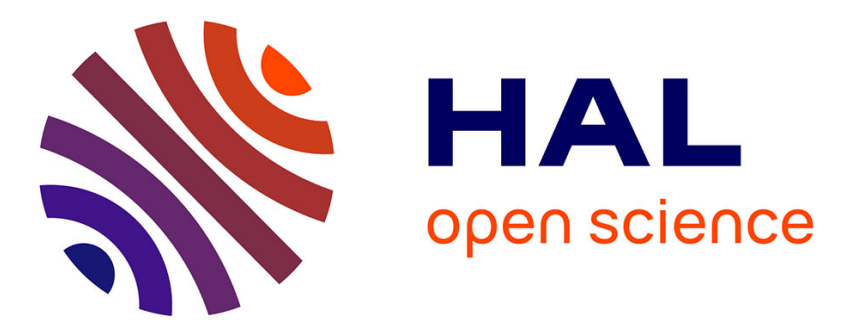

\title{
The unfolding clinical spectrum of POLG mutations
}

M J Blok, B J van den Bosch, E Jongen, A Hendrickx, C E de Die-Smulders, J E Hoogendijk, E Brusse, M de Visser, B T Poll-The, J Bierau, et al.

\section{To cite this version:}

M J Blok, B J van den Bosch, E Jongen, A Hendrickx, C E de Die-Smulders, et al.. The unfolding clinical spectrum of POLG mutations. Journal of Medical Genetics, 2009, 46 (11), pp.776. 10.1136/jmg.2009.067686 . hal-00552698

\section{HAL Id: hal-00552698 https://hal.science/hal-00552698}

Submitted on 6 Jan 2011

HAL is a multi-disciplinary open access archive for the deposit and dissemination of scientific research documents, whether they are published or not. The documents may come from teaching and research institutions in France or abroad, or from public or private research centers.
L'archive ouverte pluridisciplinaire HAL, est destinée au dépôt et à la diffusion de documents scientifiques de niveau recherche, publiés ou non, émanant des établissements d'enseignement et de recherche français ou étrangers, des laboratoires publics ou privés. 


\section{The Unfolding Clinical Spectrum of POLG Mutations}

M J Blok ${ }^{1}$, B J van den Bosch ${ }^{1,2}$, E Jongen ${ }^{1}$, A Hendrickx ${ }^{1}$, C E de Die-Smulders ${ }^{1}$ J E Hoogendijk ${ }^{3}$, E Brusse $^{4}, \mathrm{M}$ de Visser ${ }^{5}$, B T Poll-The ${ }^{6}, \mathrm{~J} \mathrm{Bierau}^{1}$, I F de Coo ${ }^{7}, \mathrm{H} \mathrm{J}$ Smeets ${ }^{1,2}$

1. Department of Clinical Genetics, Maastricht University Medical Centre, Maastricht, the Netherlands

2. Department of Genetics and Cell Biology, Maastricht University Medical Centre, Maastricht, the Netherlands

3. Department of Neurology, University Medical Center Utrecht, Rudolf Magnus Institute of Neuroscience Utrecht, The Netherlands

4. Department of Neurology, Erasmus MC University Medical Center, Rotterdam, The Netherlands

5. Department of Neurology, Academic Medical Centre, University of Amsterdam, The Netherlands

6. Department of Pediatrics, Emma's Children Hospital, University of Amsterdam, Amsterdam, The Netherlands

7. Department of Neurology, Erasmus MC University Medical Center, Rotterdam, the Netherlands

* M.J. Blok and B. van den Bosch contributed equally to this paper

Correspondence to: Dr B J van den Bosch, Department of Clinical Genetics, Maastricht University Medical Centre, PO Box 5800, 6202 AZ Maastricht, The Netherlands; bianca.vandenbosch@gen.unimaas.nl 


\section{ABSTRACT}

Background. Mutations in the DNA polymerase-gamma $(P O L G)$ gene are a major cause of clinically heterogeneous mitochondrial diseases, associated with mtDNA depletion and multiple deletions.

Objective. To determine the spectrum of POLG mutations in our Dutch patient cohort, to evaluate the pathogenicity of novel mutations and to establish genotypephenotype correlations.

Results. We identified 64 predominantly recessive mutations in 37 patients from a total of 232 patients, consisting of 23 different mutations. The substitution p.A467T was most frequently observed $(n=23)$, but was as frequent in childhood cases as in adult cases. Five new pathogenic recessive mutations, p.Lys925ArgfsX42, p.R275X, p.G426S, p.A804T and p.R869Q were identified. The known dominant CPEO mutation p.R943H was for the first time associated with premature ovarian failure as well. In 19 patients we identified only a single recessive mutation, or a sequence variant with unclear clinical significance. Our data substantiate earlier observations that in $P O L G$ patients a fatal status epilepticus and liver failure can be triggered by sodium valproate. It is therefore important to exclude POLG mutations before administering this treatment.

Conclusion. We conclude that the clinical features of the patient are the most important features to select putative $P O L G$-mutation carriers and not the presence of mtDNA deletions or OXPHOS activity. We conclude that POLG mutations are an important cause of heterogeneous mitochondrial pathology and that more accurate genotype-phenotype correlations allow a more rapid genetic diagnosis and improved prognosis for mutation carriers. 


\section{INTRODUCTION}

Maintenance of the mtDNA is critical for the mitochondria to function properly and depends on the replication machinery and nucleotide availability. The most important enzyme involved in mtDNA replication is the polymerase gamma $(P O L G)^{1}$, which consists of a polymerase domain, a 3'-5' exonuclease domain with proofreading activity, connected by a linker region, involved in $P O L G$ processing. ${ }^{2}$ Mutations in $P O L G$ are being reported in a growing number of patients with mitochondrial disorders, displaying a broad range of clinical features. Over 100 different dominant or recessive mutations have been described throughout the entire gene, which were familial, sporadic or of unknown origin (http://tools.niehs.nih.gov/polg/), and genotype-phenotype correlations are beginning to emerge. ${ }^{3}$

The objective of this study was 1) to determine the spectrum of mutations in our Dutch patient cohort, 2) to evaluate the pathogenicity of novel mutations and 3) to establish genotype-phenotype correlations for $P O L G$ mutations, including clinical manifestations, activities of the complexes of the respiratory chain and the presence of mtDNA deletions.

\section{MATERIALS AND METHODS}

\section{Patients}

A total of 232 patients was screened for POLG mutations. These patients were diagnosed in multiple clinical centres and presented with one or more of the following clinical symptoms: (chronic) progressive external ophthalmoplegia, ptosis, cerebellar ataxia (SCA-negative), polyneuropathy, Alpers-syndrome, liver failure, epilepsy or status epilepticus, intestinal pseudoobstruction, congenital hypotonia, migraine, 
premature ovarian failure, failure to thrive and/or the presence of multiple mtDNA deletions/depletions in muscle. An extensive list of clinical features associated with POLG-mutations was recently published. ${ }^{3}$

\section{Sequence analysis of the POLG gene}

Sequence primers were designed to amplify all protein encoding POLG exons and at least 40 nucleotides of the flanking introns (see Supplementary Data table 1 and table 2 for PCR primers and reaction conditions). Sequences were analysed using Mutation Surveyor (Softgenetics, PA, USA) using NCBI nucleotide NM_002693.1 as reference sequence.

\section{Criteria to determine pathogenicity of new POLG mutations}

A mutation was considered new if it was neither present in the Human DNA POLG mutation database (http://tools.niehs.nih.gov/polg/) and the NCBI dbSNP database (http://www.ncbi.nlm.nih.gov/projects/SNP/index.html), nor published. A mutation was considered pathogenic when 1) a well conserved amino acid was altered in preferably a conserved region and affecting a functionally relevant site; 2) it was not present in 100 randomly selected blood donors from the Dutch population; 3) it segregated with disease in the family and 4) similarities with known pathogenic mutations regarding biochemical defects were present. Effects on splicing were investigated in silico using http://www.fruitfly.org/seq tools/splice.html, http://www.cbs.dtu.dk/services/NetGene2/,

http://www.genet.sickkids.on.ca/ ali/splicesitefinder.html and http://rulai.cshl.edu/tools/ESE/). In silico prediction of functional consequences was performed using Align GVGD (http://agvgd.iarc.fr/agvgd input.php), SIFT 
(http://blocks.fhcrc.org/sift/SIFT.html) and PolyPhen (http://genetics.bwh. harvard.edu/pph/). These last three tools support a possible pathogenic role if an effect is determined. However, this will not always be the case, as, for example, these kind of in silico tools cannot predict the effect on protein-protein interactions.

\section{RESULTS}

\section{General overview POLG mutations}

For the 232 patients (table 1) in this study, a total of 64 mutations was identified in 37 index patients, consisting of 23 different mutations. These mutations explained the clinical features in 18 patients (patients 6 to 23, table 1), 17 of whom had two known recessive mutations and one a dominant mutation. Most common was p.A467T, which was compound heterozygous in 10 patients and homozygous in 5 patients. In 200 Dutch controls we did not detect this mutation, so the carrier frequency seems less than $0.5 \%$. For the remaining 19 patients, only one single known recessive mutation was found in 10 patients and a single new mutation in 5 patients. They can not by themselves explain the clinical features observed. In 4 additional patients we found the p.G517V mutation that was previously reported as a dominant mutation, but its pathogenicity is questionable.

\section{Novel POLG mutations and variants}

Seven previously unreported variants were identified in six patients (table 1, patients 1-6), i.e. p.Lys925ArgfsX42, p.R275X, p.G426S, p.A804T, p.R869Q and p.Q45R together with p.D136E. None of the variants was found in a control panel of 100 individuals and they all affect evolutionary conserved amino acids, except for the p.D136E variant (figure 2). The pathogenicity of p.Q45R and p.D136E is unclear, 
whereas p.Lys925ArgfsX42, p.R275X, p.G426S, p.A804T and p.R869Q are considered pathogenic mutations. The mutations p.Lys925ArgfsX42 and p.R275X were found in compound with a known recessive pathogenic mutation, whereas for the other novel mutations no second $P O L G$ mutation was found. To check for a digenic cause, all POLG patients with a single mutation were screened for mutations in Twinkle, DGUOK, TK2 and TP, but no mutations were found. Variants p.S305R and p.S1095R have been reported in patients as the only $P O L G$ variant present making the clinical relevance unconfirmed. ${ }^{4}$ In two of our patients (patient 15 and 22, table 1) these two variants were found in combination with a known recessive pathogenic mutation.

\section{Frequency and phenotypic characteristics of $P O L G$ mutations}

The p.A467T mutation is the most common mutation in our patient cohort, representing $40 \%$ of all alleles with a sequence variant. Homozygous p.A467T mutations were detected in 5 patients, compound heterozygous in 10 patients and as a single mutation in 3 patients. The most common compound heterozygous combination was with the p.W748S mutation $(n=3)$. Of the 18 index patients for whom the clinical features are explained by the presence of 2 recessive or 1 dominant pathogenic mutation (Table 1, patients 6-23), 12 patients were adults and 6 were children ( $<16$ years). Of the childhood cases, 4 girls and 1 boy were compound heterozygotes for the p.A467T mutation and died at a young age, except for 1 girl. The p.A467T mutation was as common in the childhood-onset cases $(83 \%, 5$ out of 6$)$ as in adult-onset cases $(83 \%, 10$ out of 12). All index patients with homozygous p.A467T mutations were in the group of adult cases. The second most common mutation is the syntenic combination p.[T251I; P587L]. It was detected 7 times $(11 \%$ 
of all mutations), i.e. 4 times as compound heterozygous and 3 times as a single mutation. Only one known dominant mutation, p.R943H was detected in a family with POF and CPEO. In the group of patients with only one mutation, the p.G517V mutation was detected most frequently $(n=4)$, but the pathogenicity is questionable based on segregation and population data.

\section{DISCUSSION}

\section{Novel pathogenic POLG mutations}

\section{p.Lys925ArgfsX42}

Patient 6 (table 1) was a compound heterozygote for the new mutation p.Lys925ArgfsX42 in the polymerase domain and the p.A467T mutation. The patient died of status epilepticus and liver failure at the age of one and a half. The healthy parents are heterozygous carriers (figure 1). The p.Lys925ArgfsX42 mutation results in a premature stop codon at position 966 and is pathogenic by either removing part of the catalytic domain of polymerase gamma and/or leading to nonsense-mediated mRNA decay. In general, these mutations are recessive (http://tools.niehs.nih.gov/polg/) as demonstrated for the p.L965X mutation. ${ }^{5}$

\section{p.R275X}

The novel p.R275X mutation was compound heterozygous with the known recessive combination p.[T251I; P587L $]^{6,7}$ in a patient with CPEO and mental retardation (table 1, patient 2). The p.R275X is located within the second highly conserved motif (exo II) in the exonuclease domain and is predicted to remove a large part of the downstream functional $P O L G$ domains and/or leads to nonsense-mediated mRNA decay. The sister and 2 daughters of the patient only carry the p.R275X mutation 
(figure 1). The sister displays similar, albeit less severe, clinical symptoms including CPEO and one of the daughters presented with fatigue and the other with fatigue and muscle pain. Two other daughters carried only the p.[T251I; P587L] mutations, one unaffected and one diagnosed with multiple sclerosis and muscle pain. Parents of the index patient were not available for testing. Most likely the p.R275X mutation is recessive and the complaints of the carriers should have a different cause, although clinical symptoms in carriers cannot be completely excluded.

\section{p.G426S}

The novel POLG mutation p.G426S was identified in a patient with cerebellar ataxia, epilepsy, myoclonus, cognitive delay and juvenile cataract (table 1, patient 3). Her brother and sister, both carrying the same mutation, also have epilepsy and additionally juvenile cataract and asthma (figure 1). Parents of the index patient were unavailable. This mutation is likely pathogenic (table 2). The mode of inheritance is unclear, although the mutation is not located in the region where most dominant mutations are present. An unaffected brother carries the same mutation as well as his daughter, who has a history of epileptic seizures, most likely stress-related. She remains to be neurologically examined in more detail. Family history further revealed juvenile cataract in the offspring of a maternal aunt. The available data do not provide a conclusive answer regarding its mode of inheritance.

\section{p.A804T}

In patient 4 (table 1), who presented with general fatigue, muscle complaints and dysarthria, we only identified the novel p.A804T mutation. Based on amino acid and structural alignment with T7 DNA polymerase, the late linker region, including the 
p.A804 residue, is located in the predicted thumb domain known to interact with the DNA. ${ }^{8}$ Two other recessive pathogenic mutations, p.R807P and p.R807C, in this thumb domain were reported as compound heterozygous in patients with $\mathrm{PEO}^{9,10}$ and SANDO (sensory ataxic neuropathy dysarthria ophtalmoplegia syndrome). ${ }^{11}$ Polyphen and SIFT prediction results indicate that the substitution is of little significance and neutral, but the for this domain relevant protein-DNA interactions are not fully taken into account by the in silico tools. Based on the genetic data of the patient only it is likely that the p.A804T mutation is a recessive pathogenic mutation.

\section{p.R869Q}

A single new p.R869Q mutation was identified in a patient with myopathy, severe sensomotor axonal polyneuropathy, ataxia and ptosis (table 1, patient 5). The deceased father of the patient might have had ptosis as well. All three prediction programs indicate a possibly damaging effect on protein function (table 2) and it is the highest conserved site of all our novel variants identified (figure 2). The p.N864S mutation, which is present in the same conserved thumb domain ${ }^{8}$, shows a comparable high level of conservation and is associated with MNGIE-like (mitochondrial neurogastrointestinal encephalopathy) syndrome clinical symptoms. ${ }^{7}$ The mode of inheritance remains unclear.

\section{Novel unclassified $P O L G$ variants}

The novel variants p.D136E and p.Q45R were identified as compound heterozygous in a patient who presented with epilepsy during fever at the age of one and a half (table 1, patient 1). His affected brother also carried both variants. The father with the p.Q45R substitution had cataract, while the healthy mother carried the p.D136E 
substitution. The $\mathrm{D}$ at this position is not highly conserved, and $\mathrm{E}$ is also present in Xenopus and Drosophila, making a pathogenic role questionable (table 2). The p.Q45R substitution interrupts a polyglutamine tract (polyQ), encoded by a CAGrepeat in exon 2, at the most conserved position. ${ }^{12}$ Another variant in the same conserved domain, i.e. p.Q43R, was also unclassified. ${ }^{13}$ The identified variants were not present in a Dutch control panel, but the patient is not Caucasian and an ethnically matched control panel was not available. Therefore, due to lack of further information, the clinical significance of both variants remains currently unclear.

\section{Recessive mutations previously reported as the only variant detected in POLG}

In patient 15 (table 1), the p.S305R mutation was detected together with the p.A467T mutation (table 1 and 2) in a patient with Alpers syndrome. Recently, this mutation has been reported as the only mutation present in a one-year-old patient with Alpers syndrome. ${ }^{4}$ It is located within a conserved region of the $P O L G$ gene, which also includes the known pathogenic mutation p.L304R. ${ }^{14}{ }^{15}$ In patient 22, we identified the p.S1095R mutation in combination with the known recessive pathogenic p.D1184N

mutation. ${ }^{16}{ }^{17}$ Her healthy parents are both carrier of one of the mutations (figure 1). Recently, the p.S1095R mutation has been identified in a patient with CPEO, but as the only mutation in $P O L G .^{4}$ Our data confirm both mutations as recessive and pathogenic.

\section{Cases with one recessive mutation}

In 19 other patients we identified either sequence variants of unclear clinical relevance, or only a single known or new, recessive mutation (patients 1-5, 24-37, table 1). In these cases it is possible that the detection of the POLG mutation is just a 
coincidence and that the mutation causing the disease is located in another (unknown) gene. Based on the reported carrier frequencies for the p.A467T mutation we estimated the likelihood that a second mutation would be present. The allele frequency in the neighboring countries Belgium and Germany is respectively $0.6 \%$ and $0.19 \%{ }^{3,18}$ and the mutation was not found in 400 Dutch control alleles, which indicates the carrier frequency is not higher than in Germany. In 214 unresolved cases (428 chromosomes) the p.A467T was detected 3 times, which is an enrichment compared to the control population, supporting the likelihood of a second POLG mutation in an intron or promoter or a large rearrangement, which is currently not being tested.. For the detection of these kind of defects, other assays should be developed and implemented in the standard mutation screening, e.g. MLPA, allele specific detection of RNA expression and next generation sequencing to cover the complete $P O L G$ gene, including its promoter region and introns. Digenic inheritance due to a combined effect of 2 mutations in different genes on the function of the mtDNA replication system could provide an alternative explanation. ${ }^{19}$ This was proposed for the POLG p.G848S mutation in combination with a novel Twinkle mutation, ${ }^{20}$ but this latter mutation has also been found as the single mutation in two autosomal dominant PEO families. 5 , 20, 21 . Therefore, there is no solid evidence for digenic PEO inheritance at this moment.

\section{Genotype-phenotype correlations}

The p.A467T mutation and childhood versus adult cases

The p.A467T mutation is the most common mutation in the POLG-gene (http://tools.niehs.nih.gov/polg/). Biochemical studies showed that the mutated protein possesses only $4 \%$ of wild-type DNA polymerase activity, while it failed to 
interact with and was not stimulated by the accessory subunit POLG2. ${ }^{22}$ The late onset ptosis in carriers of an Austrian family ${ }^{23}$, was not present in carriers of our families. Our data do not confirm the reported male gender bias ${ }^{5}$ for homozygous children, although the number of severely affected children is low in our study. We detected the p.A467T mutation as frequent in the childhood-onset as in adult cases $(83 \%)$, which is in contrast to the reported higher frequency in children $(60 \%$ versus 20\%). ${ }^{5}$ Moreover, all index patients with homozygous p.A467T mutations were in the group of adult cases. This confirms previous observations that homozygous p.A467T mutations are correlated with a later-onset form of Alpers syndrome. ${ }^{18,24-26}$ or a more chronic spectrum of disorders referred to as the ataxia-neuropathy spectrum. ${ }^{23,27,28}$

\section{Compound heterozygous p.A467T mutations}

The finding that the majority of the severe clinical cases involve one mutation in the linker domain, e.g. the p.A467T mutation, and one mutation in the polymerase domain, was not visible from our data. ${ }^{3,26}$ In concordance with this observation are the 2 families 6 and 20, in which the p.A467T mutation was detected together with the mutation p.Lys925ArgfsX42 and p.A957P, respectively. However, 2 other families do not follow this rule. The mutation p.S1095R in the polymerase domain and the mutation p.D1184N in the C-terminal part of the protein after the polymerase domain were both detected in a severe case of childhood disease (patient 22). We also detected the p.A467T mutation in combination with the p.R227P mutation, which is located in the exonuclease domain, in two sibs who died early in their second year (patient 12). The reason for this is unclear, but the original finding seems to be a simplification. 
Not all compound heterozygous p.A467T mutation carriers are at risk of severe disease. We detected the p.A467T mutation in combination with the syntenic p.[T251I; P587L] mutations in patients 13 and 14. Neither patient 13 (age 51) or her affected sisters (age 57 and 64), nor patient 14 (age 60) developed clinical features related to Alpers syndrome and all reached a high age although the presented patients are not free of symptoms (see table 1). The same combination of mutations was reported in a mildly affected patient with ptosis and proximal weakness at 45 years of age. $^{29}$ These data suggest that the p.A467T mutation in combination with the mutations p.[T251I; P587L] is associated with late onset, non-lethal disease. A nonAlpers phenotype has also been reported for patients with the p.A467T mutation and a mutation in the exonuclease domain, or the first $2 / 3$ of the linker domain. ${ }^{26}$ It is yet unclear why this combination of mutant proteins leads to relatively mild clinical features.

Homozygous versus compound heterozygous p.A467T mutation carriers and valproate treatment

In general, clinical features of homozygous p.A467T mutation carriers are initially less severe than those of compound heterozygous mutation carriers. Similar findings were reported for the p.W748S mutation. ${ }^{30}$ The difference between homozygous and heterozygous p.A467T mutation carriers is unclear, given the highly reduced POLG activity for the p.A467T mutation. An additional dominant negative effect for the heterozygous alleles, through a possible quaternary interaction between catalytic subunits in different heterotrimers composed of $P O L G$ and POLG2 subunits has been postulated. ${ }^{30}$ In particular, symptoms of Alpers syndrome appear to be triggered in p.A467T homozygotes by treatment with the widely used drug sodium valproate for 
epileptic seizures (patients 7,8 and 9; table 1). This can also be the case for heterozygous p.A467T or p.W748S carriers. The reported mean age of onset in these patients is 7 years later than for p.A467T or p.W748S homozygotes, but the median survival after onset is reported to be only 6 years versus 50 and 26 years, respectively. ${ }^{30}$ The deceased patients in their study suffered from epilepsy and developed liver failure and were all treated with sodium valproate. The surviving patients were all over age 40, did not have epilepsy and were never treated with sodium valproate. Patient 16,17 and 18 of our cohort were compound heterozygotes for the p.A467T and p.W748S mutations and showed severe clinical symptoms, including epilepsy (patient 17 and 18), but were never treated with sodium valproate and have no liver failure until now. Remarkably, one sister of patient 17 deceased at the age of 34 years of toxic liver failure, although sodium valproate had been replaced by phenytoin and carbamazepin two years before. The presence of $P O L G$ mutations in this sister was however not determined. A detrimental effect of sodium valproate use in $P O L G$ mutation carriers has been reported before ${ }^{3,5,30}$ and our data substantiate these findings. Sodium valproate is known to inhibit mitochondrial fatty acid oxidation $^{31}$ and a mitochondrial deficiency should therefore exclude its use.

\section{OXPHOS-complex activity and POLG mutations}

$P O L G$ mutations may cause deletions and/or single-base point mutations in the mtDNA and possibly a reduction in copy number. ${ }^{32}$ This can result in a measurable deficiency of the OXPHOS system, mostly detected in muscle. ${ }^{17}$ However, this is not always the case. For example, patient 22 showed normal biochemistry in muscle, while in liver reduced complex I, III and IV activity was found. Also patient 7, who suffered from multi-organ failure, including liver failure, showed normal muscle 
biochemistry, but reduced complex II activity in liver and reduced complex III activity in brain. Finally, patient 9 who died at the age of 18 of Alpers syndrome, also did not show a complex deficiency in muscle. Unfortunately, a liver biopsy was not available for testing. These findings corroborate with previous case reports in which $P O L G$-mutations are not necessarily correlated with decreased OXPHOS activity both in children ${ }^{17}$ and adults. ${ }^{25}$ We therefore conclude that the absence of a complex deficiency in a muscle biopsy does not exclude the presence of a $P O L G$ mutation. Complex activity in other affected tissues, such as liver and brain, is more likely to be reduced.

\section{POLG mutations and mtDNA-deletions}

The screening for mtDNA deletions in muscle also appears to be of limited value for the selection of those patients eligible for $P O L G$ mutation analysis. For example, patient 12, 22 and the sister of patient 7 did not show mtDNA deletions in muscle, although being severely affected, even though patient 12 did show decreased OXPHOS activity in muscle. On the contrary, in four other adults (patients 11, 14, 16, 21 and 23), all at the age over 47, multiple mtDNA deletions were detected in muscle using PCR and confirmed by Southern blotting, except for patient 11 . This is in agreement with the observation that a sensitive PCR assay will detect deleted mtDNA

in $P O L G$ patients presenting in adult life ${ }^{5,23,33}$. However, it should noted that the presence of mtDNA deletions in adult patients can be a secondary effect due to, for example, ageing. ${ }^{34,35}$ Therefore, detection of deleted mtDNA in young children could be more indicative for a $P O L G$ mutation, but absence does not exclude it. 
The clinical spectrum of $P O L G$ defects includes premature ovarian failure (POF) for the dominant $P O L G$ mutation p.Y955C in combination with PEO. ${ }^{36,} 37$ Previous structure-function studies showed that the p.Y955C mutation leads to a severe decrease $(<1 \%)$ in polymerase activity compared to wild-type. This is also the case for the dominant p.R943H mutation, which we report for the first time in a family with POF and CPEO and/or cataract (patient 23, table 1 and figure 4). This indicates that similar biochemical consequences of mutations based on functional studies can predict genotype-phenotype correlations.

\section{Reclassification of the dominant p.G517V mutation to an unclassified variant}

In four patients (34-37) we found the p.G517V mutation, which was previously reported as a dominant mutation in a single family ${ }^{5}$, but its pathogenicity and causal relation to the clinical features is questionable. We detected this mutation in a consanguineous family in three affected brothers, but also in unaffected family members (figure 5). In three additional patients, the p.G517V mutation was detected but there was no clear family history suggesting a dominant inheritance pattern. Altogether, the p.G517V should be considered as an unclassified sequence variant for which the clinical relevance is currently unclear. This is in agreement with recent findings reported by Wong et al. ${ }^{4}$ and Sarzi et al. ${ }^{38}$ who suggested that the p.G517V mutation either shows a recessive inheritance pattern or it is a rare polymorphism or modifier.

\section{CONCLUSIONS}

Mutations in the POLG gene are a common cause of OXPHOS disease and result in a broad spectrum of clinical features. The detection of five new mutations and the 
establishment of pathogenicity in our study for two recessive mutations previously reported as single variants, further expands the spectrum of $P O L G$ mutations. There is a clear need for more functional studies to confirm the pathogenicity of $P O L G$ sequence variants. The genotype-phenotype correlations for $P O L G$ mutations are unfolding, particularly for the p.A467T mutation, since most data are available for this commonly detected mutation. The p.A467T mutation is often detected in patients with severe clinical features including status epilepticus and liver failure. It is therefore important that the use of sodium valproate to treat epileptic seizures in patients with $P O L G$ mutations should be avoided since this drug appears to have strong adverse effects in these patients. Finally, since OXPHOS activity measurements and mtDNA deletion analysis both appear to be of limited value for the selection of putative $P O L G$-mutation carriers, the inclusion of patients for mutation screening should be largely driven by clinical features, of which CPEO, ataxia (preferably including epilepsy) and liver failure (particularly in young children), are important features.

\section{ACKNOWLEDGMENTS}

M.J. Blok and B. van den Bosch contributed equally to this paper. We would like to thank J.C. van Swieten for his contribution to the study.

Competing Interest: None declared. 


\section{ABBREVIATIONS}

CPEO, chronic progressive external ophthalmoplegia; MLPA, multiplex ligationdependent probe amplification; MNGIE, mitochondrial neurogastrointestinal encephalopathy syndrome; mtDNA, mitochondrial DNA; OXPHOS, oxidative phosphorylation; POF, premature ovarian failure; SANDO sensory ataxic neuropathy dysarthria ophthalmoplegia syndrome; SCA, spinocerebellar ataxia

\section{REFERENCES}

1. Clayton DA. Replication of animal mitochondrial DNA. Cell 1982;28(4):693705 .

2. Luo N, Kaguni LS. Mutations in the spacer region of Drosophila mitochondrial DNA polymerase affect DNA binding, processivity, and the balance between Pol and Exo function. J Biol Chem 2005;280(4):2491-7.

3. Hudson G, Chinnery PF. Mitochondrial DNA polymerase-gamma and human disease. Hum Mol Genet 2006;15 Spec No 2:R244-52.

4. Wong LJ, Naviaux RK, Brunetti-Pierri N, et al. Molecular and clinical genetics of mitochondrial diseases due to POLG mutations. Hum Mutat 2008.

5. Horvath R, Hudson G, Ferrari G, et al. Phenotypic spectrum associated with mutations of the mitochondrial polymerase gamma gene. Brain 2006;129(Pt 7):1674-84.

6. Lamantea E, Zeviani M. Sequence analysis of familial PEO shows additional mutations associated with the $752 \mathrm{C}-->\mathrm{T}$ and $3527 \mathrm{C}-->\mathrm{T}$ changes in the POLG1 gene. Ann Neurol 2004;56(3):454-5.

7. Van Goethem G, Schwartz M, Lofgren A, et al. Novel POLG mutations in progressive external ophthalmoplegia mimicking mitochondrial neurogastrointestinal encephalomyopathy. Eur J Hum Genet 2003;11(7):5479.

8. Chan SS, Copeland WC. DNA polymerase gamma and mitochondrial disease: Understanding the consequence of POLG mutations. Biochim Biophys Acta 2008.

9. Del Bo R, Bordoni A, Sciacco M, et al. Remarkable infidelity of polymerase gammaA associated with mutations in POLG1 exonuclease domain. Neurology 2003;61(7):903-8.

10. Di Fonzo A, Bordoni A, Crimi M, et al. POLG mutations in sporadic mitochondrial disorders with multiple mtDNA deletions. Hum Mutat 2003;22(6):498-9.

11. Gago MF, Rosas MJ, Guimaraes J, et al. SANDO: two novel mutations in POLG1 gene. Neuromuscul Disord 2006;16(8):507-9.

12. Rovio AT, Abel J, Ahola AL, et al. A prevalent POLG CAG microsatellite length allele in humans and African great apes. Mamm Genome 2004;15(6):492-502.

13. Luoma PT, Eerola J, Ahola S, et al. Mitochondrial DNA polymerase gamma variants in idiopathic sporadic Parkinson disease. Neurology 2007;69(11):1152-9. 
14. Van Goethem G, Dermaut B, Lofgren A, et al. Mutation of POLG is associated with progressive external ophthalmoplegia characterized by mtDNA deletions. Nat Genet 2001;28(3):211-2.

15. Naimi M, Bannwarth S, Procaccio V, et al. Molecular analysis of ANT1, TWINKLE and POLG in patients with multiple deletions or depletion of mitochondrial DNA by a dHPLC-based assay. Eur J Hum Genet 2006;14(8):917-22.

16. Gonzalez-Vioque E, Blazquez A, Fernandez-Moreira D, et al. Association of novel POLG mutations and multiple mitochondrial DNA deletions with variable clinical phenotypes in a Spanish population. Arch Neurol 2006;63(1):107-11.

17. de Vries MC, Rodenburg RJ, Morava E, et al. Multiple oxidative phosphorylation deficiencies in severe childhood multi-system disorders due to polymerase gamma (POLG1) mutations. Eur J Pediatr 2007;166(3):229-34.

18. Ferrari G, Lamantea E, Donati A, et al. Infantile hepatocerebral syndromes associated with mutations in the mitochondrial DNA polymerase-gammaA. Brain 2005;128(Pt 4):723-31.

19. Chinnery PF, Zeviani M. 155th ENMC workshop: polymerase gamma and disorders of mitochondrial DNA synthesis, 21-23 September 2007, Naarden, The Netherlands. Neuromuscul Disord 2008;18(3):259-67.

20. Van Goethem G, Lofgren A, Dermaut B, et al. Digenic progressive external ophthalmoplegia in a sporadic patient: recessive mutations in POLG and C10orf2/Twinkle. Hum Mutat 2003;22(2):175-6.

21. Agostino A, Valletta L, Chinnery PF, et al. Mutations of ANT1, Twinkle, and POLG1 in sporadic progressive external ophthalmoplegia (PEO). Neurology 2003;60(8):1354-6.

22. Chan SS, Longley MJ, Copeland WC. The common A467T mutation in the human mitochondrial DNA polymerase (POLG) compromises catalytic efficiency and interaction with the accessory subunit. $J$ Biol Chem 2005;280(36):31341-6.

23. Luoma PT, Luo N, Loscher WN, et al. Functional defects due to spacer-region mutations of human mitochondrial DNA polymerase in a family with an ataxia-myopathy syndrome. Hum Mol Genet 2005;14(14):1907-20.

24. Naviaux RK, Nguyen KV. POLG mutations associated with Alpers syndrome and mitochondrial DNA depletion. Ann Neurol 2005;58(3):491.

25. Nguyen KV, Ostergaard E, Ravn SH, et al. POLG mutations in Alpers syndrome. Neurology 2005;65(9):1493-5.

26. Nguyen KV, Sharief FS, Chan SS, et al. Molecular diagnosis of Alpers syndrome. J Hepatol 2006;45(1):108-16.

27. Van Goethem G, Luoma P, Rantamaki M, et al. POLG mutations in neurodegenerative disorders with ataxia but no muscle involvement. Neurology 2004;63(7):1251-7.

28. Winterthun S, Ferrari G, He L, et al. Autosomal recessive mitochondrial ataxic syndrome due to mitochondrial polymerase gamma mutations. Neurology 2005;64(7):1204-8.

29. Stewart JD, Tennant S, Powell H, et al. Novel POLG1 mutations associated with neuromuscular and liver phenotypes in adults and children. J. Med Genet 2008; In press. 
30. Tzoulis C, Engelsen BA, Telstad W, et al. The spectrum of clinical disease caused by the A467T and W748S POLG mutations: a study of 26 cases. Brain 2006;129(Pt 7):1685-92.

31. Eyer F, Felgenhauer $\mathrm{N}$, Gempel $\mathrm{K}$, et al. Acute valproate poisoning: pharmacokinetics, alteration in fatty acid metabolism, and changes during therapy. J Clin Psychopharmacol 2005;25(4):376-80.

32. Spelbrink JN, Toivonen JM, Hakkaart GA, et al. In vivo functional analysis of the human mitochondrial DNA polymerase POLG expressed in cultured human cells. J Biol Chem 2000;275(32):24818-28.

33. Van Goethem G, Mercelis R, Lofgren A, et al. Patient homozygous for a recessive POLG mutation presents with features of MERRF. Neurology 2003;61(12):1811-3.

34. Brierley EJ, Johnson MA, Lightowlers RN, et al. Role of mitochondrial DNA mutations in human aging: implications for the central nervous system and muscle. Ann Neurol 1998;43(2):217-23.

35. Corral-Debrinski M, Horton T, Lott MT, et al. Mitochondrial DNA deletions in human brain: regional variability and increase with advanced age. Nat Genet 1992;2(4):324-9.

36. Luoma P, Melberg A, Rinne JO, et al. Parkinsonism, premature menopause, and mitochondrial DNA polymerase gamma mutations: clinical and molecular genetic study. Lancet 2004;364(9437):875-82.

37. Pagnamenta AT, Taanman JW, Wilson CJ, et al. Dominant inheritance of premature ovarian failure associated with mutant mitochondrial DNA polymerase gamma. Hum Reprod 2006;21(10):2467-73.

38. Sarzi E, Bourdon A, Chretien D, et al. Mitochondrial DNA depletion is a prevalent cause of multiple respiratory chain deficiency in childhood. $J$ Pediatr 2007;150(5):531-4, 534 e1-6.

39. Lamantea E, Tiranti V, Bordoni A, et al. Mutations of mitochondrial DNA polymerase gammaA are a frequent cause of autosomal dominant or recessive progressive external ophthalmoplegia. Ann Neurol 2002;52(2):211-9.

40. Chan SS, Longley MJ, Copeland WC. Modulation of the W748S mutation in DNA polymerase gamma by the E1143G polymorphismin mitochondrial disorders. Hum Mol Genet 2006;15(23):3473-83. 
The Corresponding Author has the right to grant on behalf of all authors and does grant on behalf of all authors, an exclusive licence (or non exclusive for government employees) on a worldwide basis to the BMJ Publishing Group Ltd to permit this article (if accepted) to be published in Journal of Medical Genetics and any other BMJPGL products and sublicences such use and exploit all subsidiary rights, as set out in our licence (http://JMG.bmj.com/misc/ifora/licenceform.shtml). 
Table 1.

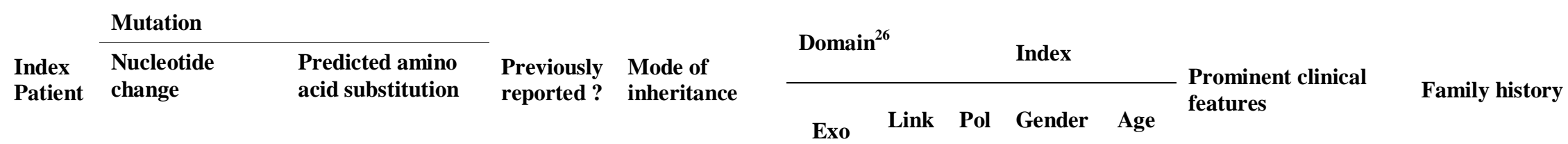

New Mutations

\begin{tabular}{|c|c|c|c|c|c|c|c|c|c|}
\hline \multirow[t]{2}{*}{1} & c. $134 \mathrm{~A}>\mathrm{G}$ & p.Q45R & $\mathrm{N}$ & AR ? & $\begin{array}{l}\text { polyQ- } \\
\text { tract }\end{array}$ & & & & \multirow{2}{*}{$\begin{array}{l}\text { Father epilepsy, carrier } \\
\text { variant c. } 134 \mathrm{~A}>\mathrm{G} \text {, mother } \\
\text { unaffected, carrier variant } \\
\text { c. } 408 \mathrm{C}>\mathrm{G} \text {, brother with } \\
\text { epilepsy has both variants } \\
\text { (figure 1) }\end{array}$} \\
\hline & c. $408 \mathrm{C}>\mathrm{G}$ & p.D136E & $\mathrm{N}$ & AR ? & + & M & 4 & Epilepsy & \\
\hline \multirow[t]{2}{*}{2} & c. $823 \mathrm{C}>\mathrm{T}$ & p.R275X & $\mathrm{N}$ & $\mathrm{AR}$ ? & + & & & & \\
\hline & $\begin{array}{l}\text { c. }[752 C>T \\
1760 C>T]\end{array}$ & p.[T251I; P587L] & $\mathrm{Y}^{39}$ & AR & + & $\mathrm{F}$ & $68^{\dagger}$ & $\begin{array}{l}\text { CPEO and mental } \\
\text { retardation }\end{array}$ & figure 1 \\
\hline 3 & c. $1276 \mathrm{G}>\mathrm{A}$ & p.G426S & $\mathrm{N}$ & AR? & + & $\mathrm{F}$ & 56 & $\begin{array}{l}\text { Ataxia, epilepsy, } \\
\text { myoclonus, cognitive } \\
\text { delay, juvenile } \\
\text { cataract, MRI showed } \\
\text { atypical white matter } \\
\text { lesions }\end{array}$ & $\begin{array}{l}\text { Brother and sister with } \\
\text { epilepsy and cataract, other } \\
\text { sister with epilepsy } \\
\text { (figure 1) }\end{array}$ \\
\hline
\end{tabular}




\begin{tabular}{|c|c|c|c|c|c|c|c|c|c|c|}
\hline 4 & c. $2410 \mathrm{G}>\mathrm{A}$ & p.A804T & $\mathrm{N}$ & $\mathrm{AR} ?$ & & + & M & 55 & $\begin{array}{l}\text { General fatigue } \\
\text { muscle complaints, } \\
\text { bulbar dysarthria }\end{array}$ & $\begin{array}{l}\text { No further family details } \\
\text { known }\end{array}$ \\
\hline \multirow[t]{2}{*}{5} & c. $2606 \mathrm{G}>\mathrm{A}$ & p.R869Q & $\mathrm{N}$ & $\mathrm{AR} ?$ & & + & & & & \\
\hline & & & & & & & M & 32 & $\begin{array}{l}\text { Myopathy with } \\
\text { extensive neurogenic } \\
\text { atrophy; severe } \\
\text { sensomotor axonal } \\
\text { polyneuropathy; ataxia } \\
\text { and ptosis }\end{array}$ & $\begin{array}{l}\text { Mutation status other family } \\
\text { members not known; Father } \\
\text { "ptosis" (not clinically } \\
\text { confirmed), no known } \\
\text { further family history }\end{array}$ \\
\hline \multirow[t]{2}{*}{6} & c.2772_2773delG & p.Lys 925 ArgfsX42 & $\mathrm{N}$ & $\mathrm{AR}$ & & + & & & \multirow[b]{2}{*}{$\begin{array}{l}\text { Prematurity, epilepsy, } \\
\text { deafness, retinitis } \\
\text { pigmentosa, status } \\
\text { epilepticus, } \\
\text { hemiparesis, liver } \\
\text { failure }\end{array}$} & \multirow[b]{2}{*}{$\begin{array}{l}\text { Healthy parents both carrier } \\
\text { (figure 1) }\end{array}$} \\
\hline & c. $1399 \mathrm{G}>\mathrm{A}$ & p.A467T & $\mathrm{Y}$ & $\mathrm{AR}$ & + & & $\mathrm{F}$ & $1^{\dagger}$ & & \\
\hline
\end{tabular}

\section{Homozygous p.A467T}

$\begin{array}{llll}\text { c.1399G }>\text { A } & \text { p.A467T } & \text { Y } & \text { AR }\end{array}$

$\mathrm{AR}$

$+\quad \mathrm{F} \quad 23^{\dagger}$

Migraine, sensory
ataxia, seizures, status

epilepticus, liver

insufficiency
Sister with cerebellar ataxia, axonal neuropathy,

migraine, initial external

opthalmoplegia, epilepsy,

myoclonic seizures, mild

mental retardation 


\begin{tabular}{|c|c|c|c|c|c|c|c|c|c|}
\hline 8 & c. $1399 \mathrm{G}>\mathrm{A}$ & p.A467T & $\mathrm{Y}$ & $\mathrm{AR}$ & + & $\mathrm{F}$ & $16^{\dagger}$ & $\begin{array}{l}\text { Focal seizures, } \\
\text { Alpers-syndrome }\end{array}$ & $\begin{array}{l}\text { Healthy parents both } \\
\text { carriers; two healthy } \\
\text { brothers carrier status } \\
\text { unknown }\end{array}$ \\
\hline 9 & c. $1399 \mathrm{G}>\mathrm{A}$ & p.A467T & $\mathrm{Y}$ & $\mathrm{AR}$ & + & $\mathrm{F}$ & $18^{\dagger}$ & Alpers-syndrome & Healthy parents both carriers \\
\hline 10 & c. $1399 \mathrm{G}>\mathrm{A}$ & p.A467T & $\mathrm{Y}$ & $\mathrm{AR}$ & + & $\mathrm{F}$ & $20^{\dagger}$ & $\begin{array}{l}\text { Alpers-syndrome (no } \\
\text { use of sodium } \\
\text { valproate) }\end{array}$ & Healthy parents both carriers \\
\hline 11 & c. $1399 \mathrm{G}>\mathrm{A}$ & p.A467T & $\mathrm{Y}$ & $\mathrm{AR}$ & + & M & 51 & $\begin{array}{l}\text { Mental retardation, } \\
\text { encephalopathy, } \\
\text { ataxia, neuropathy, } \\
\text { myopathy, CPEO, } \\
\text { polyneuropathy }\end{array}$ & $\begin{array}{l}\text { Brother died of } \\
\text { mitochondrial myopathy, } \\
\text { not tested for mutations }\end{array}$ \\
\hline
\end{tabular}

Compound heterozygous for p.A467T

\begin{tabular}{|c|c|c|c|c|c|c|c|c|c|c|}
\hline 12 & $\begin{array}{l}\text { c. } 1399 \mathrm{G}>\mathrm{A} \\
\text { c. } 680 \mathrm{G}>\mathrm{C}\end{array}$ & $\begin{array}{l}\text { p.A467T } \\
\text { p.R227P }\end{array}$ & $\begin{array}{l}\mathrm{Y} \\
\mathrm{Y}\end{array}$ & $\mathrm{AR}$ & + & + & $\mathrm{F}$ & $1^{\dagger}$ & $\begin{array}{l}\text { Failure to thrive, died } \\
\text { after status epilepticus }\end{array}$ & $\begin{array}{l}\text { Brother failure to thrive, } \\
\text { died due to encephalopathy } \\
\text { and hepatopathy at the age } \\
\text { of one }\end{array}$ \\
\hline \multirow[t]{2}{*}{13} & c. $1399 \mathrm{G}>\mathrm{A}$ & p.A467T & $\mathrm{Y}$ & $\mathrm{AR}$ & & + & & & & \multirow[b]{2}{*}{$\begin{array}{l}\text { Three other affected sisters } \\
\text { with ptosis, external } \\
\text { opthalmoplegia, proximal } \\
\text { muscle weakness, } \\
\text { polyneuropathy. Mother } \\
\text { with ataxia and diabetes, } \\
\text { died from cardiac arrest } \\
\text { without diagnosis }\end{array}$} \\
\hline & $\begin{array}{l}\text { c. }[752 \mathrm{C}>\mathrm{T} \\
1760 \mathrm{C}>\mathrm{T}]\end{array}$ & p.[T251I; P587L] & $\mathrm{Y}$ & $\mathrm{AR}$ & + & + & $\mathrm{F}$ & 51 & $\begin{array}{l}\text { Exercise intolerance, } \\
\text { CPEO, retinitis } \\
\text { pigmentosa, diabetes, } \\
\text { limb-girdle weakness }\end{array}$ & \\
\hline
\end{tabular}




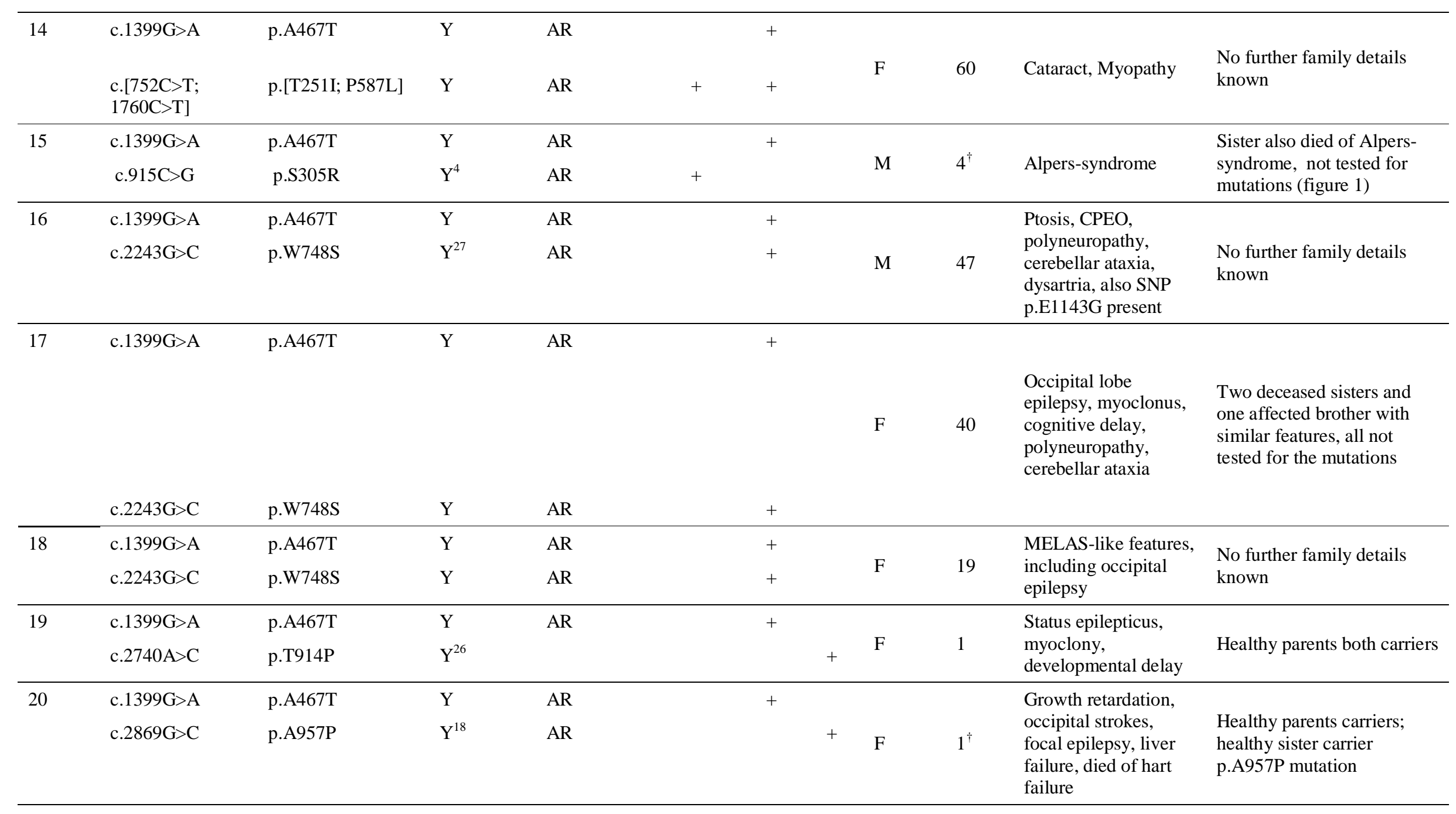


Other compound heterozygous mutations

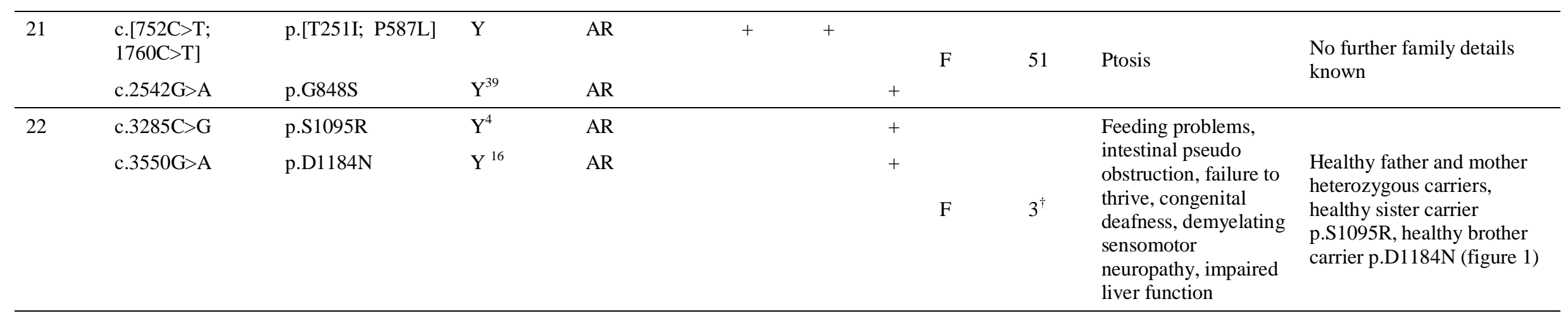

Dominant mutation

\begin{tabular}{|c|c|c|c|c|c|c|c|c|c|}
\hline 23 & c. $2828 \mathrm{G}>\mathrm{A}$ & p.R943H & $\mathrm{Y}^{39}$ & $\mathrm{AD}$ & + & $\mathrm{F}$ & 71 & POF and CPEO & Figure 4 \\
\hline
\end{tabular}

\section{Cases with only a single known recessive mutation}

\begin{tabular}{|c|c|c|c|c|c|c|c|c|c|c|}
\hline 24 & $\begin{array}{l}\text { c. }[752 \mathrm{C}>\mathrm{T} \\
1760 \mathrm{C}>\mathrm{T}]\end{array}$ & $\begin{array}{l}\text { p.[T251I; P587L] } \\
\text { Second mutation? }\end{array}$ & $\mathrm{Y}$ & $\mathrm{AR}$ & + & + & $\mathrm{M}$ & 10 & $\begin{array}{l}\text { Mental deterioration, } \\
\text { treatment resistant } \\
\text { epilepsy }\end{array}$ & $\begin{array}{l}\text { Healthy parents, father also } \\
\text { carrier of mutations }\end{array}$ \\
\hline 25 & $\begin{array}{l}\text { c. }[752 \mathrm{C}>\mathrm{T} \\
1760 \mathrm{C}>\mathrm{T}]\end{array}$ & $\begin{array}{l}\text { p.[T251I; P587L] } \\
\text { Second mutation? }\end{array}$ & $\mathrm{Y}$ & $\mathrm{AR}$ & + & + & $\mathrm{F}$ & 44 & $\begin{array}{l}\text { Cataract, cerebellar } \\
\text { syndrome, } \\
\text { polyneuropathy, } \\
\text { myopathy, ataxia }\end{array}$ & $\begin{array}{l}\text { Three brothers with a mild } \\
\text { polyneuropathy, healthy } \\
\text { parents }\end{array}$ \\
\hline
\end{tabular}




\begin{tabular}{|c|c|c|c|c|c|c|c|c|c|c|}
\hline 26 & $\begin{array}{l}\text { c. }[752 \mathrm{C}>\mathrm{T} \\
1760 \mathrm{C}>\mathrm{T}]\end{array}$ & $\begin{array}{l}\text { p.[T251I; P587L] } \\
\text { Second mutation? }\end{array}$ & $\mathrm{Y}$ & $\mathrm{AR}$ & + & + & F & 4 & $\begin{array}{l}\text { CPEO, ptosis, motor } \\
\text { development delay }\end{array}$ & $\begin{array}{l}\text { No further family details } \\
\text { known }\end{array}$ \\
\hline 27 & c. $852 \mathrm{C}>\mathrm{T}$ & $\begin{array}{l}\text { p.G268A } \\
\text { Second mutation? }\end{array}$ & $\mathrm{Y}^{9}$ & $\mathrm{AR}$ & + & & $\mathrm{F}$ & 7 & $\begin{array}{l}\text { Parkinsonism, chorea, } \\
\text { dystonia, mental } \\
\text { retardation }\end{array}$ & Consanguineous parents \\
\hline 28 & c. $852 \mathrm{C}>\mathrm{T}$ & $\begin{array}{l}\text { p.G268A } \\
\text { Second mutation? }\end{array}$ & $\mathrm{Y}$ & $\mathrm{AR}$ & + & & $\mathrm{M}$ & 3 & $\begin{array}{l}\text { Feeding problems, } \\
\text { hepatocerebral } \\
\text { syndrome }\end{array}$ & Consanguineous parents \\
\hline 29 & c. $852 \mathrm{C}>\mathrm{T}$ & $\begin{array}{l}\text { p.G268A } \\
\text { Second mutation? }\end{array}$ & $\mathrm{Y}$ & $\mathrm{AR}$ & + & & M & 16 & $\begin{array}{l}\text { Severe progressive } \\
\text { neuropathy, ptosis, } \\
\text { intestinal problems }\end{array}$ & $\begin{array}{l}\text { No further family details } \\
\text { known }\end{array}$ \\
\hline 30 & c. $1399 \mathrm{G}>\mathrm{A}$ & $\begin{array}{l}\text { p.A467T } \\
\text { Second mutation? }\end{array}$ & $\mathrm{Y}$ & $\mathrm{AR}$ & & + & F & 48 & $\begin{array}{l}\text { Neurodegeneration, } \\
\text { impaired cognitive } \\
\text { functions }\end{array}$ & $\begin{array}{l}\text { Deceased sister with similar } \\
\text { clinical features }\end{array}$ \\
\hline 31 & c. $1399 \mathrm{G}>\mathrm{A}$ & $\begin{array}{l}\text { p.A467T } \\
\text { Second mutation? }\end{array}$ & $\mathrm{Y}$ & $\mathrm{AR}$ & & + & M & 19 & Spinocerebellar ataxia & $\begin{array}{l}\text { No further family details } \\
\text { known }\end{array}$ \\
\hline 32 & $\begin{array}{l}\text { c. } 1399 \mathrm{G}>\mathrm{A} \\
\text { c. } 3428 \mathrm{~A}>\mathrm{G}\end{array}$ & $\begin{array}{l}\text { p.A467T } \\
\text { p.E1143G }\end{array}$ & $\begin{array}{l}\mathrm{Y} \\
\mathrm{Y}^{40}\end{array}$ & $\begin{array}{l}\text { AR } \\
\text { Polymorphism/ } \\
\text { modulation } \\
\text { effect other } \\
\text { mutations }\end{array}$ & & + & M & 19 & Epilepsy, myoclony & $\begin{array}{l}\text { Mother with epilepsy, } \\
\text { carrier p.E1143G, } \\
\text { father without symptoms, } \\
\text { carrier p.A467T }\end{array}$ \\
\hline & & Second mutation? & & & & & & & & \\
\hline 33 & c. $1402 \mathrm{~A}>\mathrm{G}$ & $\begin{array}{l}\text { p.N468D } \\
\text { Second mutation? }\end{array}$ & $\mathrm{Y}^{36}$ & $\mathrm{AR}$ & & + & F & $15^{\dagger}$ & $\begin{array}{l}\text { Progressive cerebellar } \\
\text { atrophy, } \\
\text { microcephaly, } \\
\text { retinitis pigmentosa, } \\
\text { hypotonia }\end{array}$ & $\begin{array}{l}\text { One sister also had the } \\
\text { p.N478D mutation Other } \\
\text { sister similar clinical } \\
\text { features, died of aortic } \\
\text { stenosis, not tested for } \\
\text { mutation }\end{array}$ \\
\hline
\end{tabular}




\begin{tabular}{|c|c|c|c|c|c|c|c|c|c|}
\hline \multicolumn{10}{|c|}{ p.G517V } \\
\hline 34 & c. $1550 \mathrm{G}>\mathrm{T}$ & p.G517V & $\mathrm{Y}^{5}$ & $\mathrm{AD} ?$ & + & M & 34 & $\begin{array}{l}\text { Cerebellar ataxia, } \\
\text { dystonia, mild mental } \\
\text { retardation }\end{array}$ & Figure 5 \\
\hline 35 & c. $1550 \mathrm{G}>\mathrm{T}$ & p.G517V & $\mathrm{Y}$ & $\mathrm{AD} ?$ & + & M & 10 & $\begin{array}{l}\text { One single } \\
\text { unexplained attack of } \\
\text { status epilepticus, } \\
\text { fully recovered }\end{array}$ & $\begin{array}{l}\text { No further family details } \\
\text { known }\end{array}$ \\
\hline 36 & c. $1550 \mathrm{G}>\mathrm{T}$ & p.G517V & $\mathrm{Y}$ & $\mathrm{AD} ?$ & + & M & 4 & $\begin{array}{l}\text { Early onset ataxia, } \\
\text { CPEO, hypotonia }\end{array}$ & $\begin{array}{l}\text { No further family details } \\
\text { known }\end{array}$ \\
\hline 37 & c. $1550 \mathrm{G}>\mathrm{T}$ & p.G517V & $\mathrm{Y}$ & $\mathrm{AD} ?$ & + & $\mathrm{F}$ & 40 & $\begin{array}{l}\text { Mental retardation } \\
\text { and chorea while } \\
\text { giving birth }\end{array}$ & $\begin{array}{l}\text { Sister with similar clinical } \\
\text { features }\end{array}$ \\
\hline
\end{tabular}

AR, autosomal recessive; $\mathrm{AD}$, autosomal dominant; $\mathrm{CPEO}$, chronic progressive external ophthalmoplegia; MELAS, mitochondrial encephalomyopathy, lactic acidosis, and stroke-like episodes; POF, premature ovarian failure; $\dagger$, deceased. 
Table 2. Characteristics of novel variants in POLG.

\begin{tabular}{|c|c|c|c|c|c|c|c|c|c|c|c|}
\hline Variant & $\begin{array}{l}\text { Cons. } \\
\mathbf{A A}^{\mathrm{a}}\end{array}$ & Domain & $\begin{array}{l}\text { Found in } \\
\text { trans } \\
\text { with }^{b}\end{array}$ & $\begin{array}{l}\text { Present in } \\
100 \\
\text { controls }\end{array}$ & $\begin{array}{l}\text { Near } \\
\text { established } \\
\text { mutations }\end{array}$ & $\begin{array}{l}\text { Polarity } \\
\text { change }\end{array}$ & $\begin{array}{l}\text { Charge } \\
\text { change }\end{array}$ & $\begin{array}{l}\text { Grantham } \\
\text { score }^{c}\end{array}$ & Align GVGD class & Polyphen & SIFT \\
\hline \multicolumn{12}{|c|}{ Novel pathogenic mutations } \\
\hline p.Lys925ArgfsX42 & STOP & Poly & p.A467T & No & p.L965X $X^{5}$ & N.A. & N.A. & N.A. & N.A. & N.A. & N.A. \\
\hline p.R275X & STOP & $\begin{array}{l}\text { Exo } \\
\text { (motif II) }\end{array}$ & $\begin{array}{l}\text { p.T251I; } \\
\text { p.P587L }\end{array}$ & No & No & N.A. & N.A. & N.A. & N.A. & N.A. & N.A. \\
\hline p.G426S & Yes & Exo & $\begin{array}{l}\text { No } 2^{\text {nd }} \\
\text { mutation }\end{array}$ & No & p.L428P $\mathrm{P}^{38}$ & $\mathrm{NP}$ to $\mathrm{P}$ & No & 56 & C0 (least likely) & $\begin{array}{l}\text { Possibly } \\
\text { damaging }\end{array}$ & Affects protein function \\
\hline p.A804T & Yes & $\begin{array}{l}\text { Poly? } \\
\text { Link? }\end{array}$ & $\begin{array}{l}\text { No } 2^{\text {nd }} \\
\text { mutation }\end{array}$ & No & $\begin{array}{l}\text { p.R807P } \\
\text { p.R807C } \\
\text { (1) }\end{array}$ & NP to $\mathrm{P}$ & No & 58 & C0 (least likely) & Benign & Tolerated \\
\hline p.R869Q & Yes & Poly & $\begin{array}{l}\text { No } 2^{\text {nd }} \\
\text { mutation }\end{array}$ & No & p.N864S ${ }^{7}$ & No & $\begin{array}{l}\text { Basic to } \\
\text { neutral }\end{array}$ & 43 & $\begin{array}{l}\text { C35 (medium } \\
\text { likely) }\end{array}$ & $\begin{array}{l}\text { Possibly } \\
\text { damaging }\end{array}$ & Affects protein function \\
\hline \multicolumn{12}{|c|}{ Novel variants of unclear clinical relevance } \\
\hline p.Q45R & Yes & $\begin{array}{l}\text { PolyQ } \\
\text { tract }\end{array}$ & p.D136E & No & No & No & $\begin{array}{l}\text { Neutral } \\
\text { to basic }\end{array}$ & 43 & C0 (least likely) & Benign & Tolerated \\
\hline p.D136E & No & Exo & p.Q45R & No & No & No & No & 45 & C0 (least likely) & Benign & Tolerated \\
\hline \multicolumn{12}{|c|}{ Recessive mutations previously reported as the only variant detected in $P O L G$} \\
\hline p.S305R & Yes & Exo & p.A467T & No & p.L304R ${ }^{1415}$ & No & $\begin{array}{l}\text { Neutral } \\
\text { to basic }\end{array}$ & 110 & C0 (least likely) & Benign & Tolerated \\
\hline p.S1095R & Yes & Pol & p.D1184N & No & $\begin{array}{l}\text { p.R1096C } \\
\text { p.R1096H } \\
5,21\end{array}$ & No & $\begin{array}{l}\text { Neutral } \\
\text { to basic }\end{array}$ & 110 & C0 (least likely) & $\begin{array}{l}\text { Possibly } \\
\text { damaging }\end{array}$ & Affects protein function \\
\hline
\end{tabular}

${ }^{\mathrm{a}}$ see amino acid (AA) alignment data figure 2 ; $^{\mathrm{b}}$ see also table 1 ; $^{\mathrm{c}}$ The Grantham matrix predicts the effect of AA substitutions based on chemical properties; stop: leading to a

stopdocon; N.A.: not applicable; NP: non-polar; P: polar. Poly: polymerase domain. Exo: exonuclease domain. Link : linker domain. 

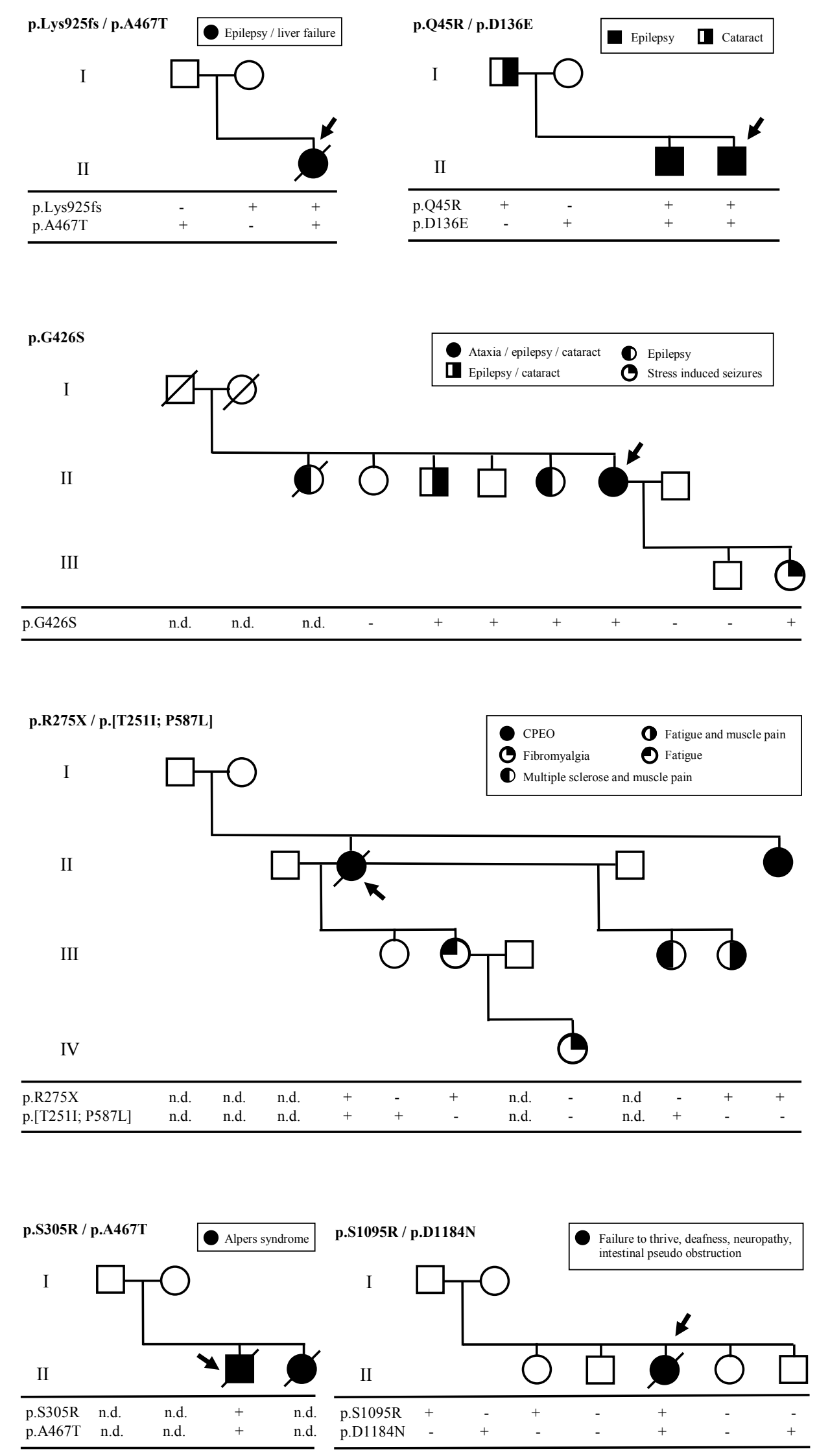

Figure 1 Family trees with segregation pattern of (new) mutations.

+ , mutation carrier; -, mutation not detected; n.d., not determined. 
Homo sapiens

Pan troglodytes

Macaca mulatta

Rattus norvegicus

Xenopus laevis

D. melanogaster

S. Cerevisiae

S. pombe

Neurospora crassa

Consensus

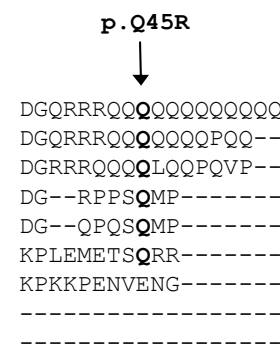

LRWDSTIAQVLERKG---

\[ \]
PPLYGDNLDQHFRLLAQ
PPLYGDNLDQHFRLLAQ
PPLYGDNLDQHFRLLAQ
PRLFGGNLDQHFRLLAQ
PRLFGGNLDQHFRLLAQ
PKMYGNNIEEHFQILAQ
PPLRGANIEEHFHNIAK
PPLQGRSLDEHFQKIGR
PPLQGKTISEHFYNIGL
PALVGDTLDEHKLIGV
PPL G NLD HFRLLAQ

$\bigsqcup_{\text {CPHPVTLAGMLEMGVSY }}^{\text {p.G426S }}$

CPHPVTLAGMLEMGVSY CPHPVTLAGMLEMGVSY CPHPVTLAGMLEMGVSY CPHPVTLAGMLEMGVSY CPHPVTLAGMLEMGVSY CPHPVTLSGMLEMGVSY FPHPASLAGMLEMGSAY CPHPVSFAGLKSLSKCI CPHPATFSAMLSLGSVF CPHPVSFAALRHLASV

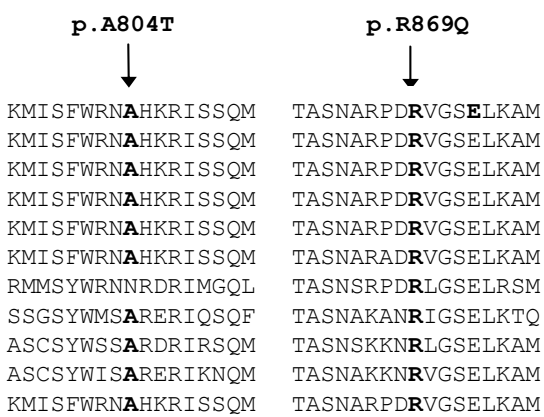

Figure 2

Amino acid alignment of the human $P O L G$ reference sequence versus various species. Indicated are the positions of the novel variants identified. This alignment was adapted from the Human DNA Polymerase Gamma Mutation Database (http://tools.niehs.nih.gov/polg/). 


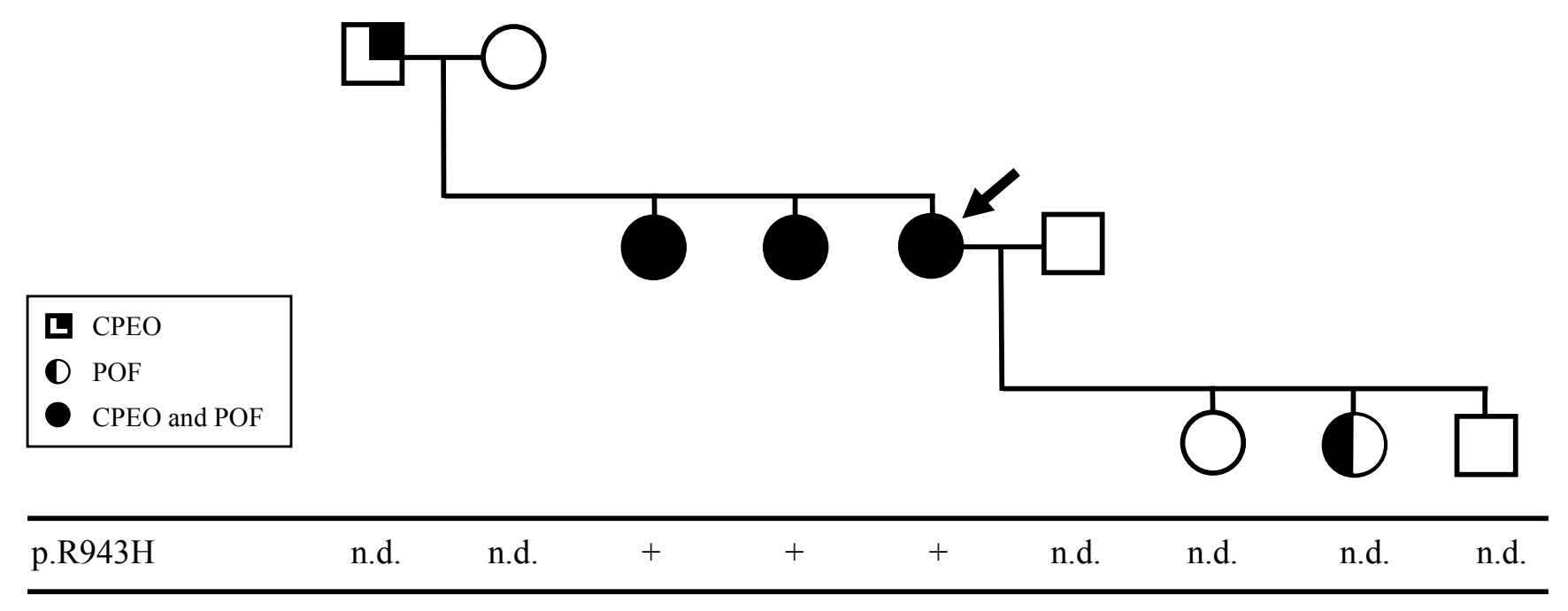

Figure 3 p.R943H mutation in a family with POF and CPEO, including index patient 23. + , mutation carrier; n.d., not determined. 


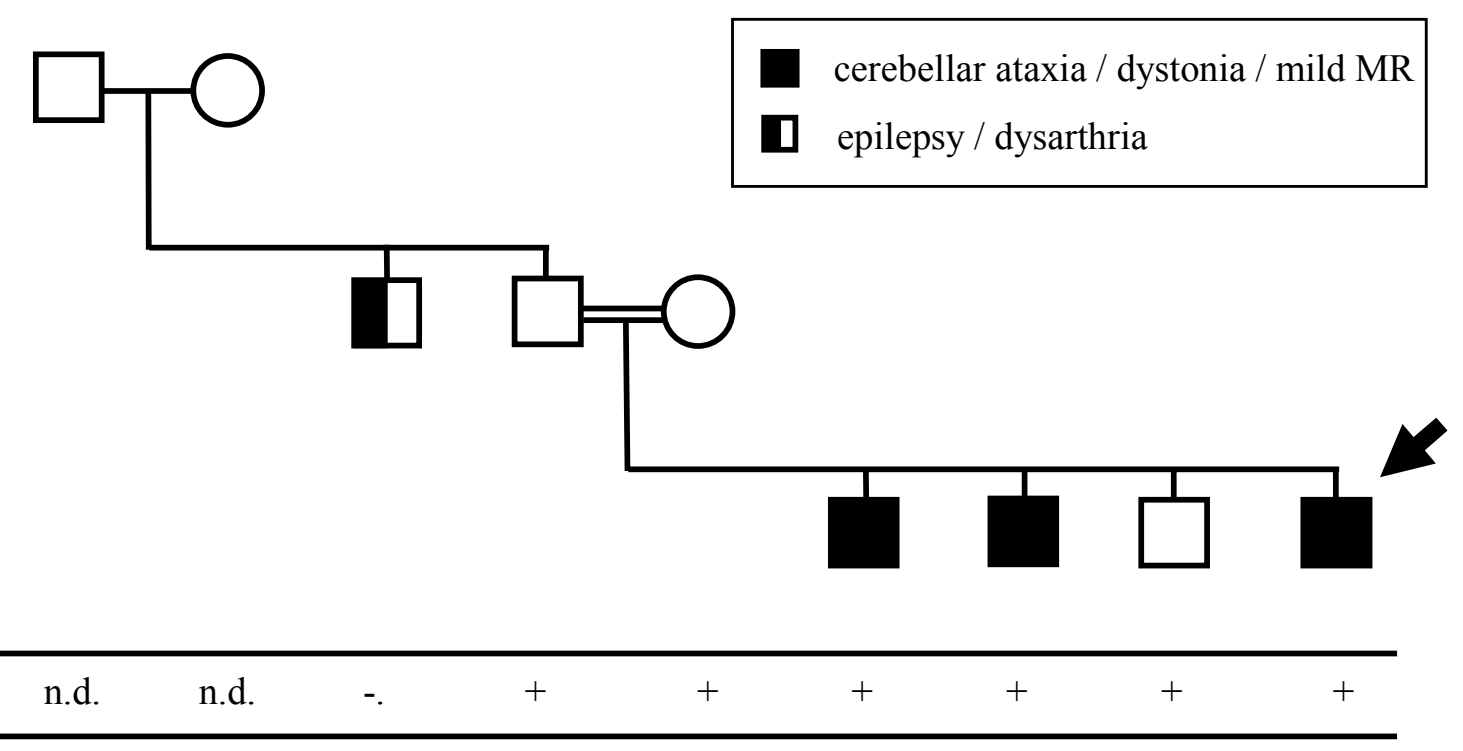

Figure 4 Family with p.G517V sequence variant, including index patient 34. +, mutation carrier; -, mutation not detected; n.d., not determined. 